\title{
Bronchoalveolar lavage in pulmonary mycotoxicosis (organic dust toxic syndrome)
}

\author{
R LECOURS, M LAVIOLETTE, Y CORMIER \\ From the Centre de Pneumologie, Hôpital Laval, Sainte-Foy, Québec, Canada
}

\begin{abstract}
Two cases of pulmonary mycotoxicosis (organic dust toxic syndrome) are described in which bronchoalveolar lavage was undertaken during the acute phase and after recovery. Both cases $\underset{\perp}{\perp}$ occurred after exposure to mould dust in a silo in the course of removing the top mouldy layer of $\bigcirc$ silage or oats at the start of unloading. The workers suffered an acute febrile illness accompanied by $\rightarrow$ cough and dyspnoea. One patient had impaired ventilatory function and both had arterial $\mathbb{\Phi}_{\mathbb{D}}$ desaturation in the acute phase. There was mild impairment of diffusing capacity (transfer factor). Bronchoscopy showed inflammation of the bronchial mucosa in one patient. Fungal spores were cultured from the lavage fluid in both patients. In both patients there was an increase in the percentage of neutrophils in the lavage fluid without increase in lymphocytes. The immunoglobulin concentration in the lavage fluid was normal. At the follow up lavage the neutrophils had returned to normal while a mild lymphocytosis of the lavage fluid was seen in both patients.
\end{abstract}

An acute bronchopulmonary response to a massive inhalation of fungal spores has previously been described and termed pulmonary mycotoxicosis. ${ }^{1}$ The condition is also known as organic dust toxic syndrome. Typically acute pulmonary mycotoxicosis presents as a febrile illness with dry cough, dyspnoea, and inspiratory crackles beginning a few hours after exposure to a large quantity of spores. Silo unloading is the principal occupational setting. The chest radiograph shows either normal appearances or minimal interstitial infiltration. ${ }^{1}$ Symptoms usually resolve spontaneously after withdrawal from exposure and the disease leaves no sequelae. APM must be distinguished from acute extrinsic allergic alveolitis. A recent presentation of 30 cases by May et al suggests that the incidence of APM is grossly underestimated. ${ }^{2}$ To our knowledge no data on bronchoalveolar lavage fluid in acute pulmonary mycotoxicosis have been published. We report two cases of APM and present the cellular biochemical aspects of bronchoalveolar lavage fluid both at diagnosis and at follow up.

Address for reprint requests: Dr Y Cormier, Hôspital Laval, 2725 Chemin Ste-Foy, Sainte-Foy (Québec) G1V 4G5, Canada

Accepted 30 June 1986

\section{Case reports}

CASE 1

Three hours after decapping a corn silo, a 26 year old non-smoking dairy farmer develped a dry cough, dyspnoea, chills, and a frontal headache. The silo had $\stackrel{\sim}{\times}$ been filled nine months previously. Twelve hours after $\dot{\sigma}$ his exposure to extremely moldy silage he had a fever 3 . of $39^{\circ} \mathrm{C}$, but no wheezes or crackles. The chest radio- $\delta$ graph was normal. Peripheral blood analysis showed $₹$ a white blood cell count of $17.5 \times 10^{9} / 1$ with $95 \%$ 윽 neutrophils. The forced vital capacity (FVC) and $D$ FEV $_{1}$ were decreased to $67 \%$ and $51 \%$ of predicted values with an $\mathrm{FEV}_{1} / \mathrm{FVC}$ ratio of 0.63 ; there was no $N$ improvement after bronchodilator inhalation (sal- $\sigma$ butamol $200 \mu \mathrm{g}$ ). The total lung capacity (TLC) was $\tilde{N}$ $87 \%$ of the predicted value and the carbon monoxide $\underset{\omega}{ }$ transfer factor (TLCO) steady state $69 \%$ of predicted normal. The arterial oxygen tension $\left(\mathrm{PaO}_{2}\right)$ was 620

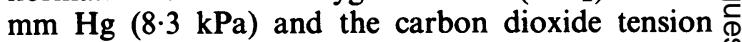
$\left(\mathrm{PaCO}_{2}\right) 33 \mathrm{~mm} \mathrm{Hg}(4.4 \mathrm{kPa})$. Bronchoalveolar lavage ?? was carried out by fibreoptic bronchoscopy. The $T$ bronchial mucosa appeared to be inflamed; little $\stackrel{\vec{P}}{\circ}$ secretion was evident. Lavage fluid was processed as $\stackrel{\Omega}{\Omega}$ previously described ${ }^{3}$; the results showed appreciable $\stackrel{\mathbb{Q}}{\Omega}$ neutrophilic alveolitis (table). Direct microbiological $\bar{\sigma}$ analysis of the bronchial aspirates disclosed no bac- 
Analysis of bronchoalveolar fluid in two patients with pulmonary mycotoxicosis

\begin{tabular}{|c|c|c|c|c|c|c|c|c|c|}
\hline & $\begin{array}{l}\text { Time } \\
\text { (days)* }\end{array}$ & $\begin{array}{l}\text { Fluid } \\
\text { recovered (\% } \\
\text { of infused }) * *\end{array}$ & $\begin{array}{l}\text { Total number } \\
\text { of cells } \\
\left(\times 10^{4} / \mathrm{ml}\right)\end{array}$ & $\begin{array}{l}\text { Macrophages } \dagger \\
(\%)\end{array}$ & $\begin{array}{l}\text { Lymphocytest } \\
(\%)\end{array}$ & $\begin{array}{l}\text { Neutrophils } \dagger \\
(\%)\end{array}$ & IgG/alb & $\operatorname{Ig} A / a l b$ & IgM/alb \\
\hline Case 1 & $\begin{array}{r}1 \\
40 \\
211\end{array}$ & $\begin{array}{l}66 \\
60 \\
48\end{array}$ & $\begin{array}{r}175 \\
18 \\
7\end{array}$ & $\begin{array}{l}31 \cdot 5 \\
67 \\
75\end{array}$ & $\begin{array}{l}7 \cdot 5 \\
31 \cdot 5 \\
21\end{array}$ & $\begin{array}{l}61 \\
1 \cdot 5\end{array}$ & $\begin{array}{l}0.02 \\
0.17 \\
0.22\end{array}$ & $\begin{array}{l}0.04 \\
0.11 \\
0.17\end{array}$ & $\begin{array}{l}\text { ND } \\
\text { ND } \\
\text { ND }\end{array}$ \\
\hline Case 2 & 3 & 49 & 85 & $48 \cdot 5$ & $7 \cdot 5$ & 43.5 & 0.55 & 0.07 & 0.02 \\
\hline & 32 & & 39 & $73 \cdot 5$ & 24 & 2.5 & 0.24 & 0.13 & ND \\
\hline $\begin{array}{l}\text { Volunteers: median } \\
\text { (range)§ }\end{array}$ & - & $\begin{array}{l}69 \cdot 7 \\
(82 \cdot 7-4 \cdot 5)\end{array}$ & $\begin{array}{c}5 \cdot 6 \\
(1 \cdot 8-14 \cdot 4)\end{array}$ & $\begin{array}{l}90 \cdot 7 \\
(60 \cdot 0-98 \cdot 7)\end{array}$ & $\begin{array}{c}6 \cdot 3 \\
(1 \cdot 0-39 \cdot 8)\end{array}$ & $\begin{array}{c}1 \cdot 5 \\
(0-4 \cdot 6)\end{array}$ & $\begin{array}{l}0.21 \\
(0.10-0.40)\end{array}$ & $\begin{array}{l}0.08 \\
(0-0 \cdot 16)\end{array}$ & $\begin{array}{l}0 \\
(0-0.04)\end{array}$ \\
\hline
\end{tabular}

"Time elapsed after exposure to fungi.

**Fluid recovery was always greater than $40 \%$ of infused volume.

Cell differential counts were obtained from both Wright-Giemsa and non-specific esterase stained cytocentrifuged preparations. A few eosinophils were sccasionally seen.

Immunoglobulin to albumin ratio in lavage fluid.

Forty two healthy, non-smokers (immunoglobulin results from only 15 of these).

ND-not detectable.

teria, but cultures showed Aspergillus fumigatus and $A$ nidulans. Serum precipitating antibodies were positive for Aspergillus (with the serum concentrated twofold) and negative for Micropolyspora faeni, Thermoactinomyces vulgaris (fourfold concentration).

No treatment was given and one week after his admission to hospital all symptoms had disappeared. One month later the patient was symptom free. Bronchoalveolar lavage was repeated and the results showed that a moderate lymphocytic alveolitis persisted. The chest radiographic appearance was normal. The serological reactions were negative. A third bronchoalveolar lavage was carried out six months later; the lymphocyte count was still slightly increased (table).

\section{CASE 2}

A 29 year old non-smoking dairy farmer developed a dry cough with headache, chills, and dyspnoea immediately after the removal of mouldy material from the top of an oat filled silo that had been filled a year before. After the acute reaction his cough increased and he sought medical help three days later. On admission to hospital he had a temperature of $38.6^{\circ} \mathrm{C}$ and normal chest radiographic appearances. Peripheral blood analysis showed a white blood cell count of $10.3 \times 10^{9} / 1$ with $77 \%$ neutrophils. The FVC was $94 \%$ of the predicted value, the $\mathrm{FEV}_{1} 87 \%$, and the $\mathrm{FEV}_{1} / \mathrm{FVC}$ ratio 0.74 . The maximal mid expiratory flow rate was decreased to $68 \%$ of predicted normal, increasing to $99 \%$ after inhalation of $200 \mu \mathrm{g}$ of salbutamol. TLC was $104 \%$ of predicted normal and TLCO (single breath) $82 \%$. Arterial blood gas analysis showed $\mathrm{a} \mathrm{PaO}_{2}$ of $55 \mathrm{~mm} \mathrm{Hg}(7.5 \mathrm{kPa})$ and $\mathrm{PaCO}_{2}$ of $39 \mathrm{~mm} \mathrm{Hg}(5 \cdot 2 \mathrm{kPa})$. Serum precipitins to mould antigens were negative. Cultures of the bronchial fluid showed $A$ fumigatus, $A$ nidulans, and Penicillium sp. Within two days his temperature returned to normal and the cough gradually disappeared over three weeks. One month after the acute illness the chest radiograph was normal; results of pulmonary function tests were normal, and there was a positive serological reaction to faeni (with the serum concentration twofold). Initially the lavage fluid showed a considerable neutrophilic response; this had disappeared a month later, when a slight increase of lymphocytes was present (table).

\section{Discussion}

We believe that our cases are examples of acute pulmonary mycotoxicosis as previously described, ${ }^{12}$ and that they demonstrate the differences between this clinical entity and the better known respiratory ailments extrinsic allergic alveolitis and silo filler's disease. The timing between silo filling and contact, the absence of a brownish smoke, and the absence of patchy alveolar infiltrates on the chest radiographs we believe eliminate silo filler's disease in our cases. ${ }^{5}$ Differentiation of acute pulmonary mycotoxicosis from extrinsic allergic alveolitis is more difficult. Like pulmonary mycotoxicosis, extrinsic allergic alveolitis occurs after exposure to mouldy organic matter and presents with fever and audible crackles but rarely with a normal chest radiograph. ${ }^{67}$ Transfer factor is considerably decreased in extrinsic allergic alveolitis but remains near normal in acute pulmonary mycotoxicosis. A restrictive pattern of lung disease is usually found whereas TLC is usually normal in acute pulmonary mycotoxicosis. ${ }^{28}$ Serum precipitins are usually present in high titres in extrinsic allergic alveolitis ${ }^{9}$; they were absent or barely detectable in both of our patients. The acute inflammation of the bronchial mucosa is also different from extrinsic allergic alveolitis, where bronchoscopy usually shows a normal looking bronchial tree. In the alveolitis fungus spores are rarely found, whereas these were present in both our cases. 
Our bronchoalveolar lavage findings are of interest. In the acute phase our patients had an increase in polymorphonuclear cells in the lavage fluid and a normal percentage of lymphocytes (table). An increase of polymorphonuclear cells may occur in acute extrinsic allergic alveolitis, but it is usually less pronounced and invariably associated with appreciable alveolar lymphocytosis. ${ }^{310}$ In previous studies we reported data from 22 cases of acute farmer's lung disease. ${ }^{11}$ Those patients had a median of $\mathbf{4 7 . 8 \%}$ lymphocytes in their lavage fluid (range $18 \cdot 7-84.5$ ) and $6.0 \%$ neutrophils (range 0-45). In absolute numbers the patients with acute pulmonary mycotoxicosis had $13.1 \times 10^{4}$ and $6.4 \times 10^{4}$ lymphocytes $/ \mathrm{ml}$ of lavage fluid while patients with acute farmer's lung had a median lymphocyte count of $30.6 \times 10^{4}$ (range $12 \cdot 6-71.0) / \mathrm{ml}$. Differences in neutrophils were even more striking: our two patients with acute pulmonary mycotoxicosis had 106.7 $\times 10^{4}$ and $37 \times 10^{4}$ cells $/ \mathrm{ml}$ while patients with farmer's lung had a median of 2.5 $\times 10^{4}$ (range $\left.0-18.9\right) / \mathrm{ml}$. In our two cases sequential lavage samples showed a relative alveolar lymphocytosis $\left(<10 \times 10^{4}\right.$ cells $\left./ \mathrm{ml}\right)$ and normal neutrophil $\left(<1.0 \times 10^{4}\right.$ cells $\left./ \mathrm{ml}\right)$ counts; in healthy volunteers the counts were: lymphocytes, median $0.36 \times 10^{4}$ (range 0.02-3.58) cells/ml; neutrophils, 0.07 (0-0.04) cells $/ \mathrm{ml}$ (table). In this later phase an erroneous diagnosis of extrinsic allergic alveolitis could be made; the lymphocyte count was, however, lower than that found in acute and chronic extrinsic allergic alveolitis. ${ }^{10-12}$ Lavage fluid immunoglobulin concentration may also be useful with differential diagnosis between extrinsic allergic alveolitis and acute pulmonary mycotoxicosis. We and others ${ }^{313}$ have previously found that immunoglobulins in lavage fluid are increased in extrinsic allergic alveolitis. In our two cases results were within the normal range.

Our finding of an increased number of neutrophils in lavage fluid is similar to the findings in the animal model for acute pulmonary mycotoxicosis of Marx $e t$ $a l,{ }^{14}$ and supports the histopathological findings of Emanuel et al. ${ }^{1}$ The suggested mechanism responsible for this clinical entity is the inhalation of a large amount of toxin produced by the fungi, with a resulting inflammatory reaction of the respiratory mucosa. Our two cases had heavy exposure and we did identify fungi in their lavage fluid. Edwards et $a l^{15}$ have shown that organic dusts can activate the alternative pathway of complement, and have suggested this mechanism to explain the inflammatory response seen in such patients. These workers did not believe, however, that acute pulmonary mycotoxicosis represents an entity distinct from farmer's lung.

Bronchoalveolar lavage may be a useful tool to help differentiate acute pulmonary mycotoxicosis from other bronchopulmonary diseases, especially extrinsic allergic alveolitis. Other studies, with larger $\overrightarrow{0}$ numbers of cases, will be needed to confirm the $\frac{C}{0}$ findings.

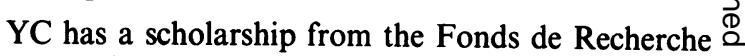
en Santé du Québec.

\section{References}

1 Emanuel DA, Wenzel FJ, Lawton BR. Pulmonary mycotoxicosis. Chest 1975;3:293-7.

2 May JJ, Sallones L, Pratt DS. Acute respiratory illness associated with silo unloading [abstract]. Am $\operatorname{Rev}$. Respir Dis 1984;129:A157.

3 Solal-Céligny $\mathrm{PH}$, Laviolette $\mathrm{M}$, Hébert J, Cormier Y Immune reactions in the lungs of asymptomatic dairy farmers. Am Rev Respir Dis 1982;126:964-67.

4 Laviolette $M$. Lymphocyte fluctuation in broncho- alveolar lavage fluid in normal volunteers. Thorax $\square$ 1985;40:651-6.

5 Fleetham JA, Munt PW, Tunnicliffe BW. Silo filler dis- $\frac{\mathbb{}}{3}$ ease. CMA Journal 1978;119:482-4.

6 Reynolds HY. Hypersensitivity pneumonitis. Clin Chest $\stackrel{\mathbb{Q}}{-}$ Med 1982;3:503-19.

7 Cormier Y, Bélanger J, Tardif A, Leblanc P, Laviolette $M$. Correlation of radiographic changes and pulmonary function tests in farmer's lung disease. Thorax 1986;41:28-33.

8 Cormier Y, Bélanger J. Long term physiological out- $\bar{\partial}$ come after acute farmer's lung disease. Chest (in ڤِ press).

9 Wenzel FJ, Gray RL, Roberts RC, Emanuel DA. Serologic studies in farmer's lung. Precipitins to the thermophilic actinomycetes. Am Rev Respir Dis 1974;109:464-9.

10 Reynolds HY, Fulmer JD, Kazmierowski JA, Roberts WC, Frank MM, Crystal RG. Analysis of cellular and protein content of bronchoalveolar lavage fluid $\frac{\mathrm{O}}{7}$ from patient with idiopathic pulmonary fibrosis and $\stackrel{\times}{\times}$ chronic hypersensitivity pneumonitis. $J$ Clin Invest $\overline{0}$ 1977;59:165-75.

11 Cormier Y, Belanger J, Leblanc P, Laviolette M. Bronchoalveolar lavage in farmers' lung disease: diagnostic $\frac{0}{3}$ and physiological significance. Br J Indust Med (in press).

12 Leblanc $\mathrm{P}$, Belanger $\mathrm{J}$, Laviolette $\mathrm{M}$, Cormier $\mathrm{Y}$. $\mathrm{D}$ Farmer's lung disease: relationship between continued exposure, alveolitis, and clinical status. Arch Intern $N$ Med 1986;146:153-7.

13 Colvanico NJ, Ambegaonkar SP, Schlueter DP, Fink N JN. Immunoglobulin levels in broncho-alveolar lavage fluid from pigeon breeders. $J$ Lab Clin Med 1980;96:129-40.

14 Marx JJ, Arden-Jones MP, Treuhaft MW, Gray RL, Motszko CS, Fletcher FH. The pathogenetic role $\mathbb{D}$ of inhaled microbial material in pulmonary? mycotoxicosis as demonstrated in an animal model. $\frac{T}{0}$ Chest 1981;suppl: 80:76-8S.

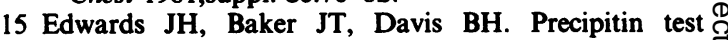
negative farmer's lung-activation of the alternative $\mathbb{D}$ pathway of complement of mouldy hay dusts. Clin Allergy 1974;4:379-88. 